技術総説

\title{
スタジオ用光源としてのキセノンランプ†
}

\author{
正会貴 西島公

\section{The Application of Xe-Lamps \\ for the Motion-Picture Studio and Television Studio lighting} \\ by Kiminobu Nishijima (Member \\ (Ushio Industrial Co. L. D.)
}

信*

\begin{abstract}
Xe-lamps have inherent properties in spectral energy, luminous efficiency, electrical operation and geometrical characteristics, which make them attractive from both technical and operational point of view as a new light source for motion-picture studio lighting.

There are two types of Xenon lamps a short arc lamp and a long arc lamp. which can be used for set or stage lighting.

For spot-lighting and projecting the short arc lamp is recommended. The short arc lamp is usually operated at d. c. voltage, but for special purpose they can be lighted by pulse voltage.

The long arc Xe-lamp is suitable for fflood-type stage illumination and generally operated at a. c. voltage. For the flickerless lighting. luminare with three lamps connected with three phase power supply is used.

There are two types of long arc lamps, the one is used by water-cooling and the other is used by natural ventilation. The power of the water-cooling lamp is $6 \mathrm{~kW}$ and the natural ventilation lamp can be manufactured in any size from $1 \mathrm{~kW}$ to $20 \mathrm{~kW}$. The total luminous flux of $20 \mathrm{~kW}$ lamp
\end{abstract} is 500,000 lumens.

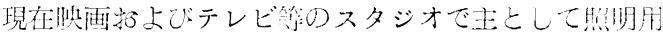
使朋されているの沈大型守熱画球であり。大体 $2 \mathrm{~kW}$

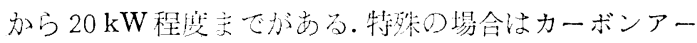
クが湖用杂れている。キセノンランプはこの方面には术 だ実用されていないが，このランプの特微より考光将决 大量に使用される可能性があるので，以下各種ランプに ついて説明する。撮影所で伎用されるランプには (1)知

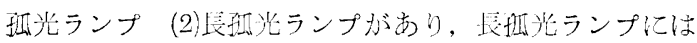
水泠式のものと筀泠式のものがある。

\section{1. 短弧光ランプ}

アーク长が大体 $10 \mathrm{~mm}$ 以下のランプで常温に扔けるキ セノンガス封入圧力は 8〜10気圧で，動作封には約 20

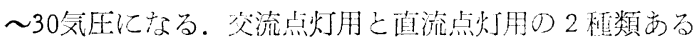

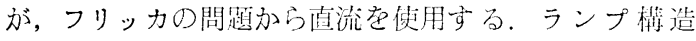
は第1図の通りである. 球状の石英バルブ中に相詨した

$\dagger \quad$ 昭和34年 4 月電気四学会シンポジウム請潞をまと めたものである

* 牛尾工業株式会社

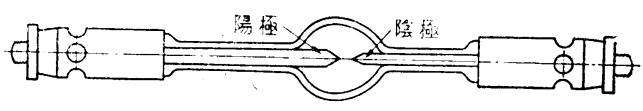

第1図キ七ノン短弧光ランプ図

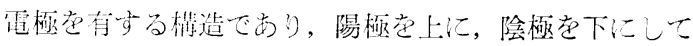

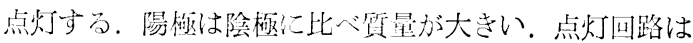
第 2 回の通りである。スタジオで侦用される此の種のラ ンプは, 1000W, 2000W，4000Wの3 種と考光られその特 性は第 1 表の通りである。用途の市ず第一にあげられる のはスポット照明である。符1表記載のようにいずれも

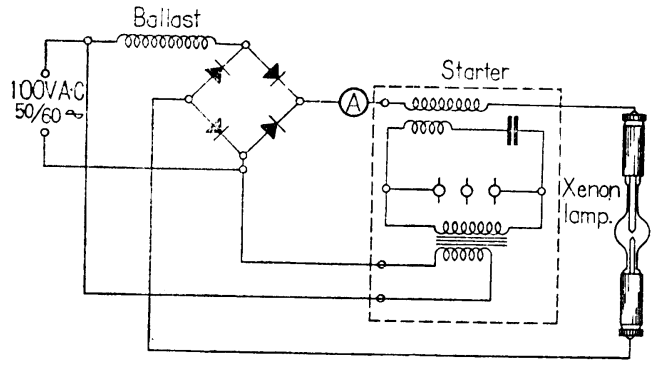

第 2 図短弧光 $\mathrm{Xe}$ lampの点灯回路 
第1表 キセノンランプの特性

\begin{tabular}{|c|c|c|c|}
\hline ランブ種数 & $U X L-1000-D$ & $\mathrm{UXL}-2000-\mathrm{D}$ & $\mathrm{UXL}-4000 \mathrm{DK}$ \\
\hline ランブワット W & 1000 & 2000 & 4000 \\
\hline ランブ刑流(最犬) $\mathrm{A}$ & 45 & 70 & 140 \\
\hline ランブ電压 V & $22 \sim 26$ & $27 \sim 31$ & $27 \sim 32$ \\
\hline アーク間腺 $\mathrm{mm}$ & 5 & 6 & 6.5 \\
\hline 束 $\operatorname{lm}$ & 28,000 & 60,000 & 130,000 \\
\hline 寿 命 (平均) $\mathrm{hr}$ & 890 & 800 & 400 \\
\hline 点灯力向 & 㨁 & 酟. & itis \\
\hline 冾 却 j $^{-}$ & 自 & 然 & 强 制 冷 却 \\
\hline
\end{tabular}

点灯 2 万加ら5万ボルトの高庄を要するので，スター 夕は灯具の下に附偊诗し，高压リードをできるだけ短 々して点灯を容易にしている。 ランプはいずれも垂直点 灯用であり，したがって灯具の操作们度は $40^{\circ}$ 以下にせ

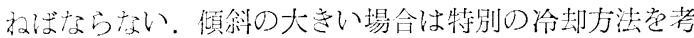
え补ば命が䓡くなる。次にあげられる用途はスクリー ンプロセス用である。テレビスタジオの場合，16 mm用 プロセスでは 1000Wで充分で, 受像管の感度が良いので， 画面照度も2001x 程度で良いようである.しかしながら

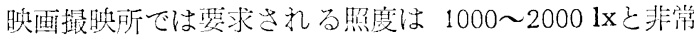
に高いので，現在 100 $200 \mathrm{~A}$ 程度の大容量のカーボン アークが使用され，な扔かつ不苋分な現淏である。カー ボンアークの場全容量が大きくなればなる程，発生熱の ため，光源孛光笔系へ近づけるととができず，したがっ て光の利用率は悲々，現在のキセノンランプの場合の約 产〜程度である。

ベックアークの $80 \mathrm{~V} 160 \mathrm{~A}$ (約13kW) のむのでリフ

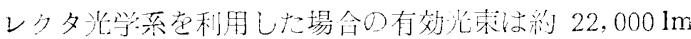

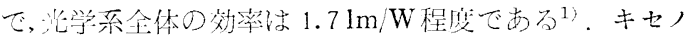

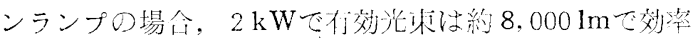
は䣋 $4 \mathrm{~lm} / \mathrm{W}$ です $4 \mathrm{~kW}$ の場全有效光東は約 $20,000 \mathrm{~lm}$

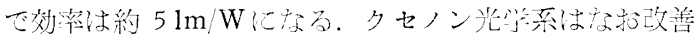

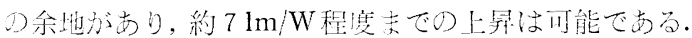

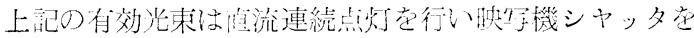
つけた場合で岁る。セノンランプはパルス点灯が可能

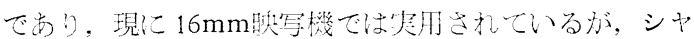
ッ夕然しの肤军ができるので，有效光恃も售近くあげる ことぶでさる。

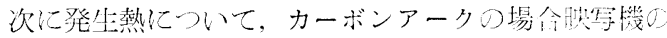
ゲート部分の受ける熱は非常に宲く一般に 400〜 $500^{\circ} \mathrm{C}$

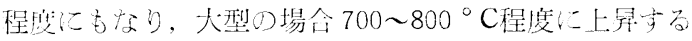
ことも专り得る。キセノンランプの場合はこの温度は。 はるかに低く然焒灰招よでスパッタがないのでコール ドミラーの使用も可能であり，非常に有利になる。

キセノンランプをスポット扎よびスクリーンプロセス 用明军機等化䛧用吉万埸合，このランプのアークの特性 を充分考虑に入れた光学系を設計与る必要がある。

第 3 図の上うに陰極附近にプラズマ球ができ最大の輝

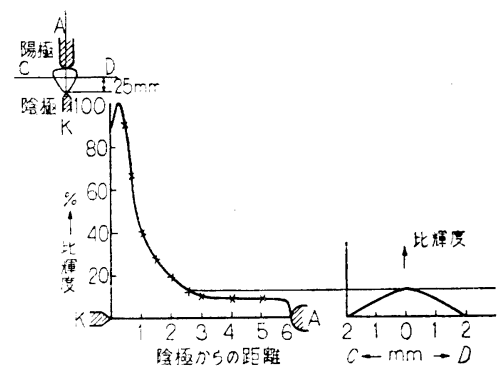

第3図キセノンアーク心棏度分有

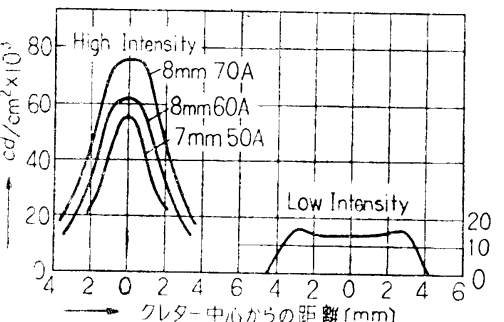

第 4 図 カーボンアーク・クレー 夕心蜖度分布
度を示し， 陽極入行く に徉って低 下し，陽極 附近ではプ ラズマ球部 分の約 $1 / 10$ 程度にな る.カーボ ンの場合は 籍 4 网のよ う比, 辉度 分布结一样 である。 たがってカ ーボンアー ク光学系の ような, 単 に反射鏡の みとか、コンデンサーレンズのみとかの焦光方式を取る 亡, 照射面の照度故が䓕しくなるので, 種々の光学系 が考光られている。またキセノンランプは色調が太陽光 に類似していることが大きな特㣲であるのて，光学系も

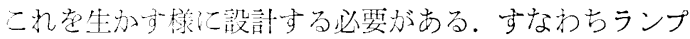
の陽㩆陰樰オ゙アークにより加熱され，約 $1800^{\circ} \mathrm{C}$ 程度に

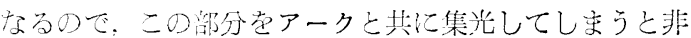
常に赤味掛った包調になる。アークのみの色温度は約

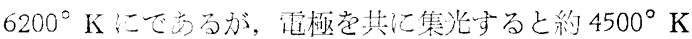
程度に色温菼は下がる。したがってアーク部分のみ在 主として背光方棣な光学系でなければ，キセノンラン プの大きな特微な失わせるととになる。

以上のような点を充分教濾てこのランプを使用すれ ばスポット用スクリーンプロセス用として良い結果が期 待できる。

\section{2. 長弧光ランプ}

\section{1. 水冷式ランプ}

このランプは主として交流点灯用として製作されたも のであり，两極間を石英細管にしてこの中を高浽アーク を通すようにしてあるのて，石英壁の温度上暈が甚だし くしたがって外部から水で令却している. 数秒間の断水 でランプが破損するので，ランプ点灯回路は第 5 図のよ うになって招り，水の循環に対する安全装犆なつけてい る. 水の速度が北常に問題になり, 遅いと冷却不充分で ランプ自体に覀影響を及汪し，また匃泡の発生が起 り, 光学系に悪影響を与えるので, 特殊な嵲環ポンプを 使用して，乙れを灯具に取付け，大体 $6 l / \mathrm{min}$ 程度の速 


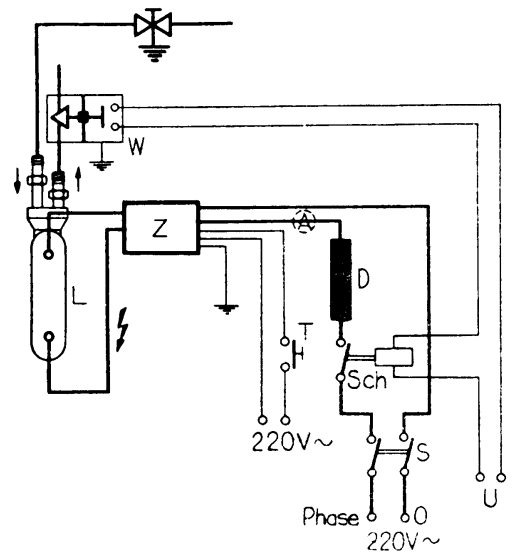

第 5 図 UXF--6000AW 点灯回路 2 表の通りである.

交流用であるので，撮影用としては3本を三相点灯し てフリッカを防ぐようにするようにする。此のランプは 横縦点灯が自目であり，フラッドな光を出すので站影用 としては非嫦に適したランプである。映画撮影の場合,

最も多く照明空要するのは，バックスクリーンの照明で あり，面積吉広く而出天然化の場合 $5.0001 \mathrm{x}$ というよう な高照度を要求されるので, 普通は10～20 kWの问熱宅 球を $2 \sim 3 \mathrm{~m}$ 間隔に使用している. この場合の有效光柦 は $20 \mathrm{~kW}$ で 24〜30 万 $1 \mathrm{~m}$ 程度である. キセノン $6 \mathrm{~kW} 3$

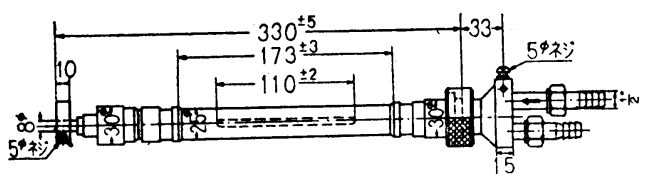

第 6 図水冷式 $6 \mathrm{~kW}$ ランプ UXF $6000 \mathrm{AW}$

灯使用に灯具は約 60 万 $1 \mathrm{~m} 0$ 光束が得られる。大体同 じ消費䉓力で約 2〜3 晔の明るさが得られることになる ので経洞的に专非常に有效である。ただしこのランプの 色温度は約 $6,000^{\circ} \mathrm{K}$ という高沿であるので, 普通の垒内 撮影用の $3,200^{\circ} \mathrm{K}$ の色浞度のフィルム在使用する場合 は，アンバ系統のフィルタを入れ色温度を下げね快なら ないので, 約 $40 \%$ 程度の光柬のロスが見迟まれら。し

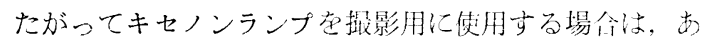
る面のみの照明ではなく, 全くセットの㬎明赵犁キセ

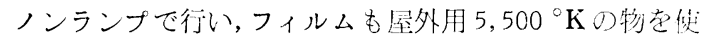
用せ衫ば効果が半減する。

\section{2. 空冷式ランプ}

前述のランプは光源の大きさがい和れも涂り大きくな いので 大きな場所の生般照明に发朋する場合に照度の ムラを起さ奴ようにする然には，ランプ数を增されば ならず経济的に相当問题がある。また水冷式であるため に取投い運搬等に若干問題が市り, 循環水の質も問题に

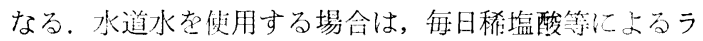

第 2 表

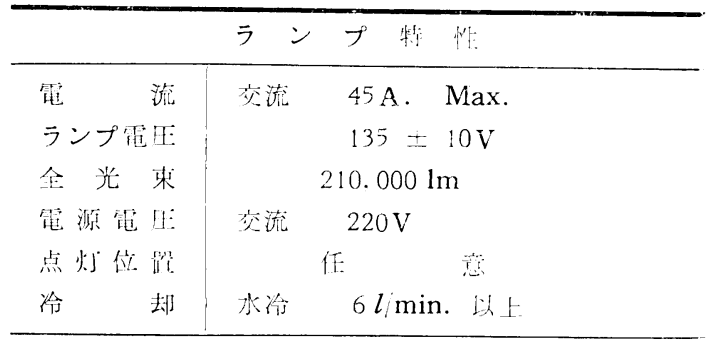

ンプの洗湺が必要で相当面倒なととになる。したがって 水冷が不要で一本で大容星のランプが要求されるしとに なる.1958年 Lichttechinik にこの蒩のランプが発表さ れだ).このランプは前述のランプと比ベ封人キセノン ガス压は非常に低く尔灯時で約1父压程度ににしかなら

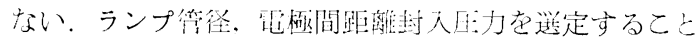

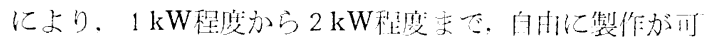

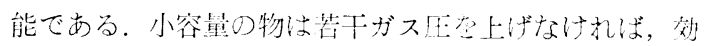
率が $25 \mathrm{~lm} / \mathrm{W}$ 以上にできないので，横些灯孛すると石

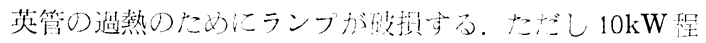

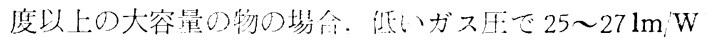

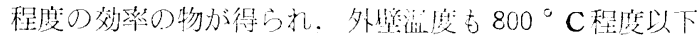
になし得るので榉点灯が可能である。 $20 \mathrm{kV}$ のンプは

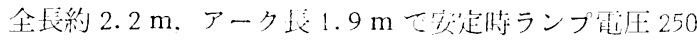

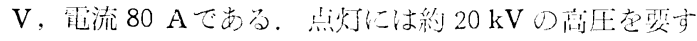

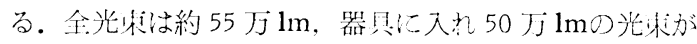
得られる。此のランプも父流点灯であるので，撮影の場 合は 3 相点灯を行いフリッカレスとして俌用する。任消 度は約 $6.000^{\circ} \mathrm{K}$ でる。 スペクトル分布は呧左になる 积輝線が增加する倾问がある。

以上简単に各ランプについて勍明したが，今後の撮影

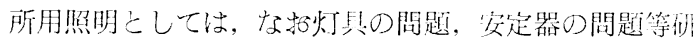
笲すがきことは相当あるが，大型ランプで全セット扎

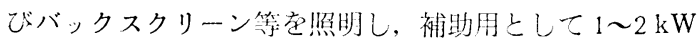
のスポット照明を行うようにすれば，キセノンランプの みによる全セット照明も可能で，隹来作栄具括上ざ俳俱

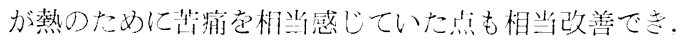
経济的には学し万有利な照明がでさる考えられる。特

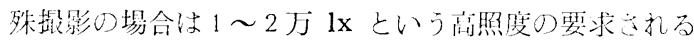
場合もあるので，此の稿ランプの利脽值も益々问上す ると教えらる。

\section{文 献}

1) H. Ulffers : Lichttech. 10 (1958) 409 416

2) Warran B. Reese : Journal SMPTE 67 (1958) 392 396

3) A. Lompe : Lichttech. $10 \quad(1958) \quad 1(8 \sim 109$ 